\title{
Die mens as sondaar - \\ Die beskouing van Karl Barth
}

\author{
F J van Zyl \\ Universiteit van Pretoria
}

\begin{abstract}
Human being as sinner: The view of Karl Barth

Karl Barth's view on the doctrine of evil, as reflected in $\mathrm{KD}$ IV/1(S 60), can be regarded as a critical correction of the theology of revolution and theology of liberation as a deviation from reformed theology - in so far as evil is no longer situated in the heart of human being, but in social, economical and political structures. In this view, people themselves are separated from sin as a quantity within themselves, instead of a quality of themselves. Consequently the sins of others are always the greatest. In contrast to this view, Barth argues that evil is not something in human being, but that human being himself/herself is a sinner, radically, totally and universally. In this article the focus is on Barth's view concerning the knowledge and the real essence of sin. In an ensuing article the question whom the sinner is will be addressed.
\end{abstract}

\section{INI FIDING}

\subsection{Vanaf Paulus na Barth}

In Augustus 1918 het daar by 'n uitgewer in die stad Zürich 'n verklaring van die 'Brief aan die Romeine' verskyn. Die outeur was die dominee van die Switserse dorp Safenwil, met die naam Karl Barth. Dit was die begin van wat later bekend gestaan het as die dialektiese teologie. Die wetenskaplike vorm waarin die Christelike geloof in hierdie Bybelse kommentaar aangebied is, was so heeltemal die 
teenoorgestelde van wat gangbaar was in die destydse kerklike wêreld, dat dit met hewige verset deur die meeste afgewys is, en deur sommiges selfs in verband met Satan en die Antichris gebring is. Daar was egter ook enkeles wat daarin 'n welkome nuwe geluid gehoor het met klanke wat herinner het aan die reformatoriese godgeleerdheid. So is die nuwe gedagtes verder gedra en het dit geleidelik ver en wyd in die kerklike wêreld weerklank gevind. In die voorwoord tot die eerste uitgawe het Barth geskrywe dat lesers sal merk aan die werk dat dit met ontdekkersvreugde geskrywe is omdat die kragtige stem van die apostel Paulus vir hom nuut was. Baie wat deur die jare ook na die kragtige stem van die apostel geluister het, soos deur Barth verwoord, sal kan getuig van die bevryding en vreugde wat dit vir hulle gebring het. Die stem van Barth het vandag in groot dele van die kerk stil geword. In die teologie het daar sedert die sestigerjare van ons eeu groot verskuiwings plaasgevind. ' $n$ Verskuiwing van die vertikale na die horisontale, van die heil na die welsyn, van die leer oor die laaste dinge en die koms van die koninkryk van God, na toekomskunde, van sonde in die hart na sonde in die strukture. Dit beteken egter nie dat die groot leermeester van die kerk vir so veel jare nie vir ons vandag nog baie te sê het nie. Miskien het dit vandag juis dringend noodsaaklik geword om weer 'n keer ernstig na hom te luister. Wat hier geskrywe word, is 'n beskeie poging om Karl Barth hoorbaar te maak oor 'n enkele aspek van die groot uitgebreide gebied wat hy in sy totale arbeid gedek het, naamlik sy leer oor die mens as sondaar.

\subsection{Enkele grondgedagtes}

Om wat later volg beter te verstaan, sal dit miskien goed wees om enkele grondgedagtes in die teologie van Barth kortliks aan te stip. Vooraf moet opgemerk word dat hierdie teologie ' $n$ reaksie is teen die humanisme en sy invloed in die teologie van de agtiende en negentiende eeu. Die humanisme is 'n denkrigting, 'n wêreldbeskouing wat streef om 'n etiek van mensliewendheid te beoefen. Dit lê alle klem op menswaardigheid, vryheid en waarde van die mens se persoonlikheid. Verder leer dit dat die mens wesenlik goed is. Miskien mag hy enkele karakterfoute hê wat in elk geval deur opvoeding herstel kan word. Die klassieke Duitse digter, Lessing, en miskien die vader van die humanisme, het geleer dat die menslike verstand die enigste lig vir die mens op sy lewensweg is. Geloof in 'n bo-wêreldlike God en aan ander godsdienstige waarhede is nie nodig nie, maar wel die insig van die mens in wat sedelik noodwendig en sinvol is op grond van sy hoogontwikkelde verstand. Geen wonder dat alle godsdienste gelyk geskakel en derhalwe van betreklike waarde gemaak word nie. Hierdie wêreldbeskouing is in die huidige tydsgewrig nie minder aktief as in die vorige eeue nie. 


\subsection{Die taak van die teologie}

Teologie is nie prediking nie, maar dit staan in diens van die kerklike verkondiging. Dit is 'n kritiese selfondersoek van die kerk na alles wat die kerk oor God Drie-Enig in die prediking sê; na wat die kerk oor die mens sê; na wat die kerk sê in sy geloofsbelydenis, in sy kategese en in sy getuienis na buite; na alles wat die kerk doen in kerk en wêreld, om vas te stel of dit alles in ooreenstemming is met wat in die Bybel as Woord van God betuig word. As 'n mens bedink dat wat deur die kerk gesê en gedoen word met die ewige bestemming van die mens te doen het, dan word dit meteens duidelik hoe 'n ontsaglike belangrike en verantwoordelike werk die teologie van die kerk is. Barth het weer erns gemaak met die spreke van die kerk in gehoorsaamheid aan die Skrif. Die Bybel is die enigste maatstaf en inhoud van wat die kerk moet sê. 'n Mens kan sy teologie dan ook tipeer as kritiese teologie van die Woord. Wat die Bybel as norm van kerklike spreke betref, het Barth nog verder as die Reformatore gegaan deur die kern van die Woord van God aan te dui as die Woord wat 'n mens geword het. Vanuit hierdie sentrale inhoud van die Bybel, Jesus Christus, benader Barth alles wat hy in sy teologie behandel. Sodra 'n mens die Bybel desentraliseer, dit wil sê anders as vanuit die Bybel se sentrum beskou, is die gevaar groot dat jy die Bybel soos ander boeke kan lees en verstaan en by die waarheid van die Skrif nog ander waarhede kan voeg wat uit ander boeke kom.

\subsection{God as die 'Onbekende God'}

In sy verklaring van die Romeinebrief maak 'n mens kennis met sekere uitdrukkings wat eintlik as simbool van Barth se totale teologiese werksaamheid gesien kan word. Een van daardie uitdrukkings wat direk aan die Bybel ontleen is, Handelinge 17:23, is sy aanduiding van God as die 'Onbekende God'. Hierdie op die oog af so onteenseglik negatiewe benaming vir God, het hom die odium, die haat en afkeer van baie sogenaamde positiewe teoloë op die hals gehaal. Inderdaad sou hierdie negatiewe uitdrukking onvrugbaar gewees het in Barth se teologie as hy nie 'n positiewe interpretasie daaraan gegee het nie. Dit het hy dan ook gedoen: ons ken God nie, maar Hy ken ons. Dit is nie so dat ons God nie kan ken vanweë negatiewe redes omdat die middele daartoe by ons ontbreek nie, maar vanweë die positiewe rede dat ons volgens Galasiërs 4:9 eerder deur God geken word. Paulus sien die weg van ons Godskennis nie van die mens af na God toe nie, maar van God af na die mens toe. Ons is voorwerpe van God se kennis, meer as Hy van ons kennis. Met hierdie vasstelling het Barth 'n wending van honderd en tagtig grade in die teologiese denke gebring. Hy het die kerk geleer om weer van God af na die mens toe te dink. 


\subsection{Godskennis}

Sonder om wat later volg vooruit te loop, kan hier opgemerk word dat Barth se beskouing van die sonde in noue verband staan met wat hy leer oor ons godskennis as deur God geken te wees. Ons is sondaars omdat ons deur God geken word. Daarom is sonde in die eerste instansie nie 'n fisiese, etiese, waarneembare, demonstreerbare feit nie, maar 'n ideële, bosinlike werklikheid. Volgens Paulus se redenasie in Romeine 7 is ons nie sondaars omdat ons die verkeerde wil doen nie, maar omdat die goeie wat ons wil doen, in die wete van God tot sonde word. Die ware begrip van sonde kom slegs in God se wete voor.

\section{KENNIS VAN SONDE}

\subsection{Kritiek teen gebruiklike opvatting}

Reeds in die Inleiding is gemeld dat Barth alle afdelings van die kerklike leer vanuit die sentrum van die Skrif benader, naamlik Jesus Christus. Daarom fundeer hy die kennis van die mens as sondaar alleen in die oorwinning van die kwaad en die vernietiging van die mens-van-sonde deur die dood en opstanding van Christus en nie in 'n selfstandige kennis van sonde voor en los van die versoening in Christus nie. Hy wys dan ook die praktyk van alle kerke in hede en verlede af wat in hulle teologiese arbeid 'n sondeleer aanbied voordat die leer oor Christus, met ander woorde die versoeningsleer, behandel is. As ' $n$ sondeleer nie in die versoeningsleer gegrond is nie en sondekennis dus nie in die kennis van Christus nie, is die eerste vraag van waar so 'n kennis van sonde dan kom?

Dit is nie moontlik dat ' $n$ mens uit jouself kan weet dat jy sondig is nie. Dat jy in verset teen God, jou naaste en jouself is nie. ' $n$ Mens mag bewus wees van baie spanninge in jou lewe, van begrensings, tekortkomings, onvolkomenhede, van die problematiek van jou bestaan in 'n wèreld van lig en skaduwee. Dit het egter nog niks met die eintlike kwaad te doen nie. Dit is by verre nog nie sonde nie. Binne die grense van selfkennis bly die moontlikheid van 'n mens nog altyd oop om jou binne jou begrensdheid te verstaan. 'n Mens kan jou begrensdheid selfs as 'n versagtende omstandigheid in jou guns sien. Selfs so iets soos hartseer en berou oor jou eie trestand is nie uitgesluit nie. So 'n berouvolle droefheid voer spoedig tot selfbejammering en dit weer lei tot selfverontskuldiging en eindig in die selfversekering dat jy tog nie te sleg is nie. Vir kennis wat die naam van sondekennis werd is, is daar in 'n selfkennis wat nie deur die Woord van God verlig en onderrig is nie, geen plek nie. Dit wat net deur die kruisdood van Jesus Christus opgehef en herstel kan word as 'n mens nie 'n sondaar wil bly en verlore wil gaan nie, word daar waar die mens net met homself besig is, nie sigbaar nie. 'n Mens beskik nou eenmaal nie oor die toegang tot jouself om jou as sondaar te kan ken en sien nie. 
Wat 'n mens uit jouself, sonder die Woord van God, oor die innerlike problematiek van jou bestaan te wete mag kom, kan ook nie as voorbereiding of voorkennis van jou sondekennis geld nie. Wat jy langs hierdie weg van jouself mag ken, sal jou nie nader bring tot 'n begrip van jou skuld en eintlike nood nie. Die teendeel is helaas waar: die werklike kwaad waarin 'n mens jou verstrik, speel nie 'n onbedenklike rol ook in die wyse waarop jy jou innerlike konflik beleef nie. 'n Mens sien en dink en ken juis verkeerd insake jou verkeerdheid, tot so 'n mate dat jy jou ook verset teen die Woord wat jou wil verlig en jou wil leer in jou verkeerdheid.

Alle ernstige, vroeëre en nuwere teologie, wat 'n leer oor die sonde vór die versoeningsleer aanbied, is eenstemmig dat sondekennis net as kennis van God en wel as openbarings- en geloofskennis moontlik en werklik is. Onder Godskennis verstaan hulle die kennis van God in sy grondverhouding tot die mens, dit wil sê die kennis van God in sy majesteit en heiligheid as Skepper en wêreldbestuurder en in die eis waarmee Hy as sodanig teenoor die mens staan. Konkreet kan dit ook beteken: die kennis van God uit sy wet, wat aan die mens van nature en algemeen deur bemiddeling van die gewete, of in die geskiedenis spesiaal geopenbaar is. Wat in die geskiedenis geopenbaar word, is veral 'n bepaalde samestellende deel van die Bybelse boodskap, verskillend van die evangelie. In hierdie kennis van God voor en buite Christus sou ons dit dan met die Woord van God te doen kry wat die besondere funksie het om die mens mee te deel dat hy 'n sondaar is en waarin sy sonde bestaan. Gekonfronteer met die heiligheid en reinheid van God sou die mens homself dan as ' $n$ ontdekte sien, ongehoorsaam aan God, in verset teen God, sy naaste en homself, die mens-van-sonde. Teen hierdie voorstelling spreek Barth hewige kritiek uit. Hy rig hom eerstens teen die veronderstelde skeiding tussen kennis van God en die Woord van God. Die idee van 'n abstrakte bestaan van God in sy suiwere Godheid as Skepper en wèreldbestuurder, en die idee van 'n abstrakte gesag en eis, is elemente wat vreemd is aan die Bybelse Godskennis en is Christelik nie bruikbaar nie. Vader, Seun en Heilige Gees is volgens Skrifgetuienis nie net in hulle innerlike bestaanswyse nie, maar ook in hulle handeling en openbaring en hulle teenwoordigheid in die wereld, een en nie geskei nie. God se ewige Woord en sy Woord wat Hy in die tyd gespreek het is een. Die een God, sy Woord en werk heet Jesus Christus. Hy is God se aangesig, God se naam, God se beeld. Buiten Hom is God nie God nie. Hy is die begin en einde van al God se weë. 'n Verdeling van God in en buite Christus is nie houdbaar nie.

Dat slegs Godskennis ook sondekennis insluit, en dat dit tot stand kom wanneer die mens met die heiligheid van God gekonfronteer word, is in die algemeen waar, maar hierdie algemene moet konkreet gevul word as dit waar wil wees. Dit kan nooit gaan om die konfrontasie van die mens met 'n abstrakte wet van 'n abstrakte 
God nie omdat so 'n God en sy wet, gemeet aan die getuienis van die Skrif, slegs 'n produk van menslike verstand en willekeurige menslike uitvinding kan wees en dus 'n onwerklikheid. Word die mens teenoor so 'n God gestel, kan beswaarlik iets anders verwag word as dat die resultaat van so 'n sondekennis nie dit is wat die Skrif daaronder verstaan nie, maar wat die mens daaronder verstaan. As die abstrakte god en wet die mens nie werklik kan vryspreek nie - dit doen immers net God in Christus - sal hy die mens ook nie werklik en waarlik kan aankla en veroordeel nie. Gestel dat daardie skeiding tussen die kennis van God en sy wet eg is. Dan sou ons buiten met God in Jesus Christus ook nog met dieselfde God in sy ander gestalte as Skepper en wêreldregeerder en met sy wet te doen hê - die wet wat vir ons algemeen bekend is deur die gewete, of in ' $n$ ingebore natuurwet of in een of ander plaasgevinde openbaring van God se wil en wet. Deur die konfrontasie met so 'n God en sy wet kan 'n mens se gevoel wel opgesweep word en verstandeliks sal 'n mens ' $n$ wesenlike verskil tussen God en mens kan vasstel. Die vraag is egter of dit 'n kennis sal wees waardeur die mens hom in verset vind teen God, sy naaste en homself, 'n verset wat hy self voltrek, waarvoor hy homself verantwoordelik voel en in die voltrekking waarvan hy homself skuldig voel? So 'n goddelike wese en wet kan wel met 'n eis tot die mens kom. Die vraag is egter hoe so 'n eis vir die mens'n verpligting kan word tot so ' $n$ mate dat hy geen rus vir homself kan vind in sy misnoeë vir homself nie, self weet dat hy aangeklaag, veroordeel en verdoem is? Die vraag is of so ' $n$ selfkennis iets anders sal wees as maar net ' $n$ ontmoeting met homself wat tot niks meer sal lei as 'n erkenning van eie onvolkomenheid? By so 'n konfrontnasie ontdek ' $n$ mens jouself in so 'n posisie dat jy jou vantevore as onskuldig beskou. Die vraag is of enige mens hom op hierdie wyse as sleg en as mens-van-sonde sal kan erken. Hierdie god is niks anders as die teruggeskaatste beeld van ons eie bestaan wat op die bosinnelike geprojekteer is en waarmee ' $n$ selfgesprek gevoer word nie. Wat 'n mens van so 'n god sou verneem is niks meer as inbeelding nie. Hierdie god is 'n afgod en ware kennis van sonde kom nie daar tot stand nie.

Dit kan eintlik nie anders nie dat 'n leer oor die sonde wat aan die leer oor Christus voorafgaan en nie daarmee rekening hou nie, bewus of onbewus, aan hierdie afgod geörienteer sal wees. Om die kwaad as sodanig vas te stel langs hierdie weg, is dit nodig om met 'n maatstaf van die goeie rekening te hou en dit aan te wend. So 'n maatstaf sal of uit Bybelse of uit filosofiese materiaal of as 'n kombinasie van die twee as 'n normbegrip van heiligheid en geregtigheid of van hoogste goed of iets anders vasgestel moet word. Die inhoud hiervan sal dan as die wese en die wil en die wet van God geld. Dit is die instansie wat van die mens gehoorsaamheid, nederigheid, liefde en oorgawe eis en die opstanci of verset 
daarteen sou dan sonde wees en vir die vergewing en beëindiging daarvan het Jesus dan in die wêreld gekom en gesterwe. As hierdie normbegrip nie uit filosofiese nie, maar uit Bybelse materiaal opgebou word, soos die geval met die Reformatore was, kan dit geluk dat 'n gepaste sondebegrip na vore kan kom. Hierdie voorbehoud is egter geen regverdiging van die metode nie. As iemand vasbeslote is om ' $n$ normbegrip los van die Bybelse middelpunt en substansie, naamlik Jesus Christus, daar te stel ter beoordeling van die mens, kan niks verhinder dat by die Skrifmateriaal ook materiaal wat elders vandaan afkomstig is, aanvullend by die Skrifprinsiep gevoeg kan word nie. Dit noem Barth 'n gedesentraliseerde verstaan van die Bybel. Dit beteken dat Jesus Christus nie meer die beheersende, alle ander omvattende middelpunt is nie, maar een onder ander. Die heillose gevaar is dat 'n mens dan die Bybel as openbaringsboek langs ander boeke gaan lê en lees soos ander boeke. Op die duur sal 'n mens nie die vraag kan ontwyk of jy die boodskap van die Bybel nie ook aanvullend uit ander boeke kan verneem nie. Die implikasie hiervan is dat die Woord van God nie meer enigste norm is vir kerk en teologie nie, maar dat ' $n$ tweede daarnaas gestel word waartoe die menslike verstand toegang het. Na die mate dat ' $n$ mens wet en sonde van nature kan leer ken uit homself omdat die wet in sy hart geskrywe is, na die mate sal sy kennis van wet en sonde nie meer geloofskennis wees nie, want dan is dit nie meer kennis deur Woord en Gees van God nie, maar kennis wat die mens onmiddelbaar deur gesprek met homself inwin. Die vraag is of 'n mens wat so 'n normbegrip ontwerp, nie die Bybel op die duur as opsioneel en nie meer as onontbeerlik sal begin sien nie. Dis onvermydelik dat 'n mens daardie kennisgrond wat baie nader aan jouself is, van nature in hart en gewete, in die plek van die Bybelse openbaring sal stel. As dit eers daartoe gekom het, lyk dit onvermydelik dat die sonde van die mens wat homself beoordeel omdat hy sy eie wetgewer, aanklaer en regter gemaak het, noodwendig 'n onskadelike saak sal blyk te wees.

Hierdie fout kan voorkom word as afgesien word van die opvatting wat 'n lang pad kom en selde betwyfel word, naamlik dat 'n leer oor die sonde die leer oor Christus voorafgaan en onafhanklik daarvan vasgestel kan word. Teenoor hierdie opvatting plaas Barth die stelling dat die mens, mens-van-sonde is, en wat sy sonde is en wat dit vir hom beteken, word geken terwyl Christus geken word, net só en werklik só. Konkreet gaan dit om die kennis van die een God wat in sy Woord mens geword het, een van ons en ons ten goede. Die kennis van hierdie God en sy versoeningswerk in Jesus Christus sluit kennis van die menslike sonde in, volledig en korrek, nêrens anders nie en in geen opsig daarvan geskei nie. Die soek na en die konstruksie van 'n normbegrip uit Bybelse en buite-Bybelse materiaal is ongegrond, oorbodig, misleidend en onbeduidend. En dit alles nie omdat Barth se metode 
beter sou wees nie, maar omdat Jesus Christus self daar is, lewe, praat, getuig en oortuig. Daarom hoef ons onsself niks oor hierdie saak te sê nie, kan ons niks sê nie en behoort ons niks te sê nie. Die mens-van-sonde, sy bestaan, sy wese, sy wie, vanwaar en waarheen staan vir ons in Jesus Christus immers voor vë. Direk, duidelik en onweerlegbaar het $\mathrm{Hy}$, as God se Woord, vir ons gesê: jy is die een, dit doen jy, so is jy. 'n Mens hoor Hom en hoor hierdie oordeel, sien Hom en sien jouself soos in 'n spieël as die een wat die sonde doen, wat die sondaar is. Hier word jy self op onontwykende wyse aangekla en onherroeplik veroordeel. In die kennis van Jesus Christus word die werklike kennis van sonde ' $n$ gebeurtenis. Juis in Jesus Christus omdat God teen wie die mens-van-sonde stryd voer, juis in hierdie mens, en juis vir my as hierdie mens, in die prysgawe en dood van sy Seun, veroordeel, in die dood gegee en vernietig het. In sy opwekking uit die dood, in sy bestaan, lewe, spreke en getuienis het $\mathrm{Hy}$ my vir alle tye as hierdie veroordeelde, indie-dood-gegewene, vernietigde openbaar en maak Hy my altyd weer openbaar. Vir elkeen van ons, ook in elkeen van ons se plek het Jesus Christus alles toe en daar ervaar. Elkeen van ons almàl is die oue mens, die sondige mens, wat dár in Jesus Christus deur God se toorn agterhaal is, veroordeel en vernietig is. In alles wat met Christus gebeur het, kry ons kennis van ons eie gesteldheid, van wat God van ons weet en hoe dit inderwaarheid met ons gesteld is.

\subsection{Kennis van sonde deur kennis van Jesus Christus}

In wat volg, wil Barth aantoon dat die gehoorsaamheid van Jesus Christus as Seun van God die spieël is waarin die mens-van-sonde herkenbaar is. Hy noem vier punte:

* Die bestaan van Jesus Christus is die plek waar ons met die menslike sonde in sy suiwere, rype en ondubbelsinnig gestalte sonder meer te doen het.

Oral en altyd bestaan sonde uit 'n verbygryp by God en uit broedermoord. Die mens is van nature geneig om God en sy naaste te haat. Altyd beteken dit verder vernietiging van die mens self deur verraad teen sy deur God goed geskape natuur. Die vraag is nou waar hierdie drie momente van sonde al drie gelyktydig aan die lig kom sodat die egtheid van die verskynsel en die werklikheid van die kwaad wat in die eenheid van die drie momente bestaan, nie betwyfel kan word nie. As een van die momente ontbreek, mag dit dalk blyk dat die mens onskuldig is. Geen Godloënaar is tegelyk ook ' $n$ vyand van mense nie, en omgekeerd. Die vraag is of daar iemand is wat homself in hierdie drieledige gestalte van die sonde bevind. Alle onsekerheid verdwyn wanneer ons kyk na die bestaan en verhouding van die mense in die Nuwe Testament teenoor Jesus. Dit gaan om die wese en verhouding van daardie mens wat, as 
ons medemens en nie beter of slegter as ons nie, nie geweet het om iets beters met Jesus aan te vang nie as wat hy daar verrig het. Dit doen hy aan Jesus wat juis vir hom ingetree het volgens God se genadige wil. Daardie mens is die vrome leier in Israel in sy fanatiese blindheid, daardie volk in sy stomheid en wankelmoedigheid, daardie staatsman en regter met sy onregverdige oordeel, daardie vroue met hulle hulpelose trane, die dissipels wat wegvlug, Petrus met sy verloëning, Judas met sy verraad. Dit is die mens van sonde in die lig van Hom vir wie dit alles aangedoen is en dit alles moes deurly het. Dit is die werklike kwaad in sy totaliteit. Omdat die mens in Jesus Christus die ewige God ontmoet, daarom is hy in die rol wat hy teenboor Jesus speel, Godloënaar. Omdat Jesus sy medemens is, is hy in die rol wat hy speel 'n mensemoordenaar. Omdat Jesus Christus die ewige Woord is deur Wie alles geskape is, vernietig die mens homself, soos Judas, en lewer hy homself aan die oordeel uit.

- Dieselfde Jesus wat só 'n teenspraak van die sondaars teen Hom verdra het, het in die lyding wat Hy daardeur ervaar het, nie net die werklikheid van menslike sonde onthul nie maar as regter ook die verwerplikheid daarvan openbaar.

Dit is ' $n$ vraag wie in staat is om die menslike bestaan en handeling as sondig te bestempel. Is dit die gewete, of die oorgelewerde norme of die stem van 'n ewige wet in die hart van die mens? Protes teen die aanklag van sulke stemme is nie net denkbaar nie, maar lankal reeds laat hoor. Wie kan hier regter wees wat beskuldig dat die weg wat gegaan word, die verkeerde weg is? In die Nuwe Testament is daar geen onsekerheid wie hierdie regter is nie. Waarom juis Christus en sy oordeel? Omdat Hy die mens van 'n plek af aanspreek, tot omkeer roep en dus die verkeerdheid sigbaar maak. Dis die plek vaanwaar hulle almal kom, waar hulle almal behoort en tuis is ondanks die rigtings en weë wat hulle inslaan. En dit wel sodat sy roepstem vir hulle nie vreemd mag wees nie; sodat sy roep, of hulle dit aanneem of nie, hulle tog feitelik aangaan; sodat met sy oordeel daadwerklik oor hulle beslis is en sodat nie onreg nie, maar in laaste en diepste sin reg deur sy oordeel aan hulle sal geskied. Twee dinge moet van hierdie plek gesê word:

* Die koninkryk wat deur Hom verkondig word en in sy persoon werklikheid geword het, is geen denkbeeldige wêreld nie waarteenoor 'n mens jou kan toe- of oopsluit nie, 'n plig of voorbehoude kan hê nie. Die Vader, as koning van hierdie ryk in wie se naam die Seun as Woord van God teenoor alle mense staan, is nie een van die baie here aan wie 'n mens jou vandag kan onderwerp en môre weer teenstaan nie, met wie 'n mens soos die skeppings van jou eie verbeelding voetbal of pop kan speel nie. Hierdie God het die mens gemaak en daarom is Hy my God en Heer, die altyd genadige 
en vriendelike Heer wat na my omsien, wat vir my sy hart oopgemaak het voordat ek mens geword het en my tot gemeenskap met Hom in sy verbond bestem het. Die mens bestaan deur God se genade en wel in die genade wat in Jesus Christus verskyn het sodat daar vir die mens geen ruimte is waarin hy hom neutraal teenoor Christus as eie meester kan beweeg nie. Wat hierdie regter onreg noem, is ongeregtigheid en vir wie $\mathrm{Hy}$ boos, sondig noem is so al stop hy ook sy ore toe.

* Hierdie Jesus met wie geen mens hom kan verbind of vergelyk nie sonder om hom onmiddellik as gediskwalifiseerd, as oortreder aangeklaag te vind nie, is ook as medemens nie sommer enigiemand van wie se standpunt, opvatting en oordeel en van die waarheid van sy woord, hy hom sou kon distansiëer nie. Teenoor Hom kan 'n mens jou nie, wat eie insig betref, terugtrek op 'n eie staanplek nie, jouself handhaaf, jou vry hou van die waarheid van sy woord en jouself onafhanklik van Hom verstaan nie. Só kan ons houding wees teenoor enige ander medemens, maar nie teenoor Hom nie. Hy is die medemens wat 'n mens nie kan ontwyk nie, van wie 'n mens nie kan afsien nie, met wie ons verbind en vergelyk is voordat ons dit self gedoen het. God het die menslike natuur met die oog op Hom geskep. Van ewigheid af het God Hom as hoof van die ganse mensheid bestem. Só is $\mathrm{Hy}$ die ewige broederlike oerbeeld van elke mens. Hy is die werklike en die lewende oor wie nie deur die wet in ons hart en gewete besluit word nie, maar $\mathrm{Hy}$ is die ewige wet wat oor ons besluit. Omdat $\mathrm{Hy}$ van hierdie plek af spreek wat kortliks aangedui is, daarom oordeel Hy reg. En omdat $\mathrm{Hy}$ net van hierdie plek af oordeel, is Hy die een wat weet wat in die mens is. Aan Hom is dit gegee om goed en sleg, reg en verkeerd te onderskei, aan die regter en aan die linkerkant te plaas. Net aan Hom ís dit gegee en net Hy doén dit dan ook. Net van Hom af is die rigting waarin die mens gaan, bekend as verkeerde rigting en wel só dat 'n om-interpretasie van hierdie verkeerdheid in 'n regte en goeie, van die begin af uitgesluit is omdat daar nie 'n staanplek is vanwaar dit gedoen kan word nie. In sy bestaan is daarvoor gesorg dat dit tot so 'n al te menslike ontwyking nie kan kom nie 'n ontwyking waarin 'n mens die sonde altyd anders as sonde waar wil laat wees soos dit teenoor alle ander instansies altyd moontlik is. Om Hom as regter te glo, te ken, te bely en te verkondig, beteken om in die lig van die ware beslissing te tree wat in sy egtheid juis daaraan herkenbaar is, dat die een wat Hom as regter glo, ken, bely en verkondig, noodwendig die eerste sal wees om te erken dat hy van almal zur sy oordeel die swaarste getref is. 
- In die bestaan van Jesus Christus is die sonde nie net in sy werklikheid en verkeerdheid bekend gemaak nie, maar ook as die waarheid van alle menslike bestaan en daad.

Hoewel onmiskenbaar en daarom nie te ontken nie, sou die kwaad in al sy gestaltes tog net as ' $n$ toevallige, uiterlike, oneintlike, verbygaande bepaling van menslike bestaan en handeling verstaan kan word. Dit is so dat dit net in bepaalde verhoudings en handelinge van die mens openbaar word, nie altyd en nie by alle mense in dieselfde opvallendheid en gevaarlikheid nie. Dit word ook nie altyd in sulke handelinge bekend waardeur ' $n$ mens van jou sondigheid bewus is nie en waarvoor jy deur ander mense onvoorwaardelik verantwoordelik gehou sou kon word nie. Dit is ook so dat 'n mens self en ander ook bewus kan wees van julle sondige dade en tog nie ophou om God se goeie skepping te wees nie. Dit is so dat die sonde ' $n$ bestemming is waar die mens hom van homself vervreem, dat hy in ' $n$ vreemde gebied en onder ' $n$ vreemde mag kom. Soos altyd is dit ook in hierdie geval die regte dinge wat geneig is om die waarheid vir ' $n$ mens te bedek waaragter jy wegkruip. Die waarheid is egter dat so seker as wat die sonde in allerlei gestaltes en dade bekend word en dat dit van mekaar verskil, so seker as wat dit is dat die mens wat dit doen, nog altyd God se goeie skepping is, so seker is dit dat die sonde nie anders bestaan as die mens se sonde nie en die mens nie anders bestaan as doener van sonde, as sondaar, as mens-van-sonde nie. Juis dit wil ons nie toegee nie en wel op die wyse dat ons daardie regte dinge wat genoem is as verskoning neem om onsself van ons sonde te onderskei, as 't ware ons bestaan van ons dade. Dit bring mee dat 'n mens so 'n neutrale 'ek' word, verskillend van jou sondige dade waaroor jy miskien spyt kan voel, maar geen rede om te skrik vir jouself nie. Daarby kom onvermydelik die voorstelling van blote viterlikheid, toevalligheid en geisoleerdheid van jou bose gedagtes, woorde en werke. Sonde kry die karakter van beroepsongevalle wat betreur word, wat ook berou kan wek en wat bely word, maar tot 'n mate ook weer goed gemaak kan word. Dan verder die onderskeiding tussen verskillende sondes: opvallendes en minder opsigtelikes; bewuste en onbewuste; swaar en maklik verklaarbares. Dan verder nog die rangskikking van sondaars wat in verskillende grade aandeel sou hê aan die verderflike van die sonde. Gevolglik die voorstelling van kleiner en groter sondaars, van goeie en slegte mense, beter en slegter mense. Omdat 'n mens jouself nie objektief kan waarneem, en jouself kan losmaak van sonde as objektiewe werklikheid nie, is die sonde van die ander altyd die grootste en reken ' $n$ mens jou by die beteres. Dit is 'n verhulling van die waarheid. 
Jesus Christus het hierdie spinneweb stukkend geskeur en die waarheid van die sonde aan die lig gebring toe Hy die saak van die sondaars sy eie gemaak het, dit oorgeneem het en voor God verteenwoordig het. Die saak van die sondaars en nie die van die regverdiges en beteres as ander nie. Wie hulle under die beteres van die mense reken, is besig om hulle aandeel aan Christus die ergste twyfelagtig te maak. Wie deel het aan Christus, het geen voorsprong bo ander nie, stel hom by die tollenaars as die agterstes in die tempel. Alleen daar is Christus en die genade van God te vind. Die waarheid van die sonde wat Jesus aan die lig bring, is dat ons dit almal doen. Deur Jesus in die middelpunt te stel, beteken nie dat die verskeidenheid en rangskikking van die sonde wegval nie. Wat wegval, is die moontlikheid om 'n rangskikking van verwerplikheid en 'n differensiasie van gevaarlikheid toe te pas. Alle sonde, groot of klein, opvallend of onopsigtelik het Hy gedra. Omdat Hy hulle dra, is die grootste nie te groot nie, maar as Hy nie ook die kleinste dra nie moet ons verlore gaan. Die waarheid van die sonde in die lig van Christus is dat dit in al sy gestaltes verwerplik is. Die waarheid is dat Christus die mense se sonde in totaliteit sy verantwoordelikheid gemaak het. Jesus het vir die hele mens in die eenheid van bestaan en daad gesterwe. Die mens is wat hy doen en hy doen wat hy is en daarom val die voorstelling van blote uiterlikheid, toevalligheid en geisoleer theid van sonde weg. Sonde is nie net ontsporings nie. Die mens is wat hy doen. Sonde is sy bose werke en daarvolgens word hy veroordeel. Die mens skrik nie net vir wat hy doen nie, maar vir homself wat nie los van sy dade staan nie.

Dit is so dat die mens as sondaar hom van homself kan vervreem: van die goeie natuur wat God hom gegee het, van sy bestemming vir God se verbond, van sy medemenslikheid. Dis waar dat die natuur van die mens in alle elemente deur die sonde verander word. Tog verdwyn sy natuur nie en dit word nie vernietig nie. Die mens van sonde is nie magtiger as sy Skepper nie en daarom kan hy nie 'n ander natuur vir homself verskaf as die een wat God hom gegee het nie. Die mens word deur die sonde nie 'n ander wese nie. Die mens bly nog homself as hy sondig: God se goeie skepping. God bly in Jesus Christus getrou aan die mens as sy goeie skepping as Hy hom uit sy dwase vergissing en vervreemding weer terugbring tot Homself. God haat die sonde, maar hou nie op om die sondaar lief te hê nie. Dit kan inderwaarheid alleen gesê word van God in Jesus Christus. Alleen die trou van God is waarborg dat die mens wat hom van homself vervreem, homself besondig en laat verdwaal, tog nie verlore gaan nie, nie tot niet gaan nie. Dit is alleen die genade van God wat hom uit daardie vervreemding en vergissing en verdwaling uithaal en weer terugbring. Wat die mens hier lewer, is net die teenstand en teenspraak teen God se trou, liefde en 
genade. Dit is die aller verskriklikste waarheid van die sonde dat die mens as goeie skepping van God wat hy is en bly homself daardie ander, vreemde, verdwaalde maak. Vir daardie onderskeiding tussen homself as 'n neutrale sondedoener en die sonde as sy bose daad, bly daar geen plek oor nie. Vir hom as God se skepping, deur God nie verlaat, nie vergeet, nie prysgegee nie, vir hom wat self in sy sondedaad alles doen wat tot sy verlorenheid moet lei, vir hom tree Jesus in die kryt. Jesus Christus het gekom om die mens in sy verlore saak te red. om die reg wat God op hom het te herstel. Die mens is in sy sonde. Die vraag is wat vergewing van daardie sonde vir hom sal beteken as hyself daardeur nie gehelp word nie. Hyself het die vernuwing nodig, en waarlik hyself is die nuwe mens wat in die gehoorsaamheid van Jesus Christus op die toneel verskyn het, en juis daardeur is hy gehelp. Maar juis daarom is hy ook weer die ou, sondige mens wat in die dood van Jesus Christus veroordeel, gedood, vernietig is en van die toneel verdwyn het, hy wat as wederstrewige teenprater voor God hom van homself vervreem het. Dit is die waarheid van die sonde. Dit bestaan nie net in die verwyt: dit het jy gedoen nie, maar in die diepste openbaring van die eintlikheid van die mens: jy is die man. Aan hierdie verwyt kan 'n mens jou nog onttrek wanneer sonde verstaan word as daad los van jou as persoon. Maar as Christus kom om as persoon in te tree vir die menslike persoon, en om die persoon van die mens te vernuwe, dan is dit duidelik dat elke mens in sy persoon mens-van-sonde is.

- Die kennis van Jesus Christus beteken ook kennis van die betekenis en volle gewig van die sonde.

Die vraag is waar dit eintlik om gaan wanneer die mens 'n mens-van-sonde genoem word. As ons probeer om die probleem ook in hierdie geval vanaf Jesus Christus te benader, dan is dit goed om van die waarheidselement van alle optimisme uit te gaan. Dit is dat vanuit die versoeningsdaad in Jesus Christus die kwaad nie net 'n mag is wat ver verwyder is van God se wil en werk nie, laat staan nog ' $n$ mag wat teenoor God staan as 'n oortreffende soewereine mag. Wat die aard van die kwaad ook mag wees, God is sy heer. So ernstig mag die kwaad nie geneem word dat dit tot 'n teengod ontwikkel met wie God om heerskappy moet stry nie. Barth praat van die kwaad, die bose, as 'n nietige, in die sin dat dit 'n niks, 'n nul is. Die kwaad is 'n gestalte van die nietige wat as sodanig eenvoudig aan God ondergeskik is. Dit word van uit die werklikheid gesê dat die kwaad deur die dood van Christus oorwin is, deur die almag van God se liefde en toorn verbreek en verpletter is. En wel só: in die oomblik toe dit die oorhand gekry het en hom op die kraste geopenbaar het, is dit in diens van God gestel en ondanks sy bose natuur moes dit instrument van die Godde- 
like triomf word. Wat ook van sy herkoms, aard en natuur gesê mag word, een ding is seker dat vanuit wat nou net gese is, die vrees ongegrond is dat ons in die kwaad met ' $n$ mag te doen het wat op dieselfde vlak as God teenoor Hom staan. Hierdie aanspraak is op Golgota eens en vir altyd geloënstraf, die onwaarheid daarvan vir altyd bewys. Die heidense voorstelling dat die kwaad 'n ewige absolute mag is teenoor God, is 'n verdigsel wat ons op 'n dwaalweg lei.

As ons die superioriteit van God oor die kwaad vanaf Jesus Christus verstaan, kan van 'n God, sonde en mens omvattende orde geen sprake wees nie. Die oortreffenheid waarin God teenoor die sonde staan, is een van 'n onvoorwaardelike 'nee' teenoor hierdie element en ook teenoor ons as verteenwoordigers van hierdie element. Hierdie ' $n$ ee' is sonder ' $n$ verborge 'ja', dis die 'nee' van die onverbiddelike toorn van God. Die sonde is God se vyand soos God die vyand van die sonde is. Sonde het geen positiewe grond in Hom nie, geen plek in sy wese nie, geen positiewe aandeel in sy lewe, wil en werk nie. Dit is geen skepping van God nie. In die geskape wêreld steek dit slegs uit as eksponent, as verteenwoordiger, van wat God nie gewil het nie, nie wil nie en nooit sal wil nie. Dis verteenwoordiger van die nietige sonder meer, van dit wat alleen insoverre is as dat God dit nie wil nie, wat alleen leef in sover dit van God verwerp, veroordeel en uitgesluit is. Deurdat die mens sonde doen, doen hy wat God verbied het en dus nie wil nie. Ook die moontlikheid daartoe het hy nie van God nie. Dat hy dit kan verwerklik, behoort ook nie tot sy vryheid as redelike wese nie. Wat vir ' $n$ vryheid is dit wat ook vryheid vir God is om Hom te gehoorsaam, ook vryheid vir die nietige wat ongeloof teenoor God is. As mens dit aan moontlikheid van die geskape natuur toeskryf, sal sonde altyd as verontskuldigbaar verklaar kan word omdat dit dan in die mens self gegrond is. In die laaste instansie is sonde egter onverontskuldigbaar. Dit het geen grond nie. Dit het geen ander moontlikheid nie as die onmontlikheid sonder meer. Sonde is net die ongerymde dwase selfbesluit om jou oop te stel vir die nietige. Hierdie absurde gebeurtenis word in Genesis 3 beskrywe waar die mens geluister het na die chaos-dier, die slang. As hierdie gebeurtenis as wil en beskikking van God sou kon plaasvind, sou al te veel gesê wees. Barth reken dat net die negatiewe gesê sou kan word: dat die mens, aangesien hy nie God is nie, na hierdie kant nie onaanvegbaar is nie en dat die plaasvind van hierdie gebeurtenis nie uitgesluit is nie. Hierdie gebeurtenis was en is egter net werklik in sy absurditeit, sy dwase ongerymdheid, sonder innerlike of uiterlike moontlikheid en sonder uiterlike of innerlike noodsaaklikheid. Hoe ernstig en ondraaglik die werklikheid van die sonde is, word eers begryp deur die feit dat God die voltrekking van sy toorngerig daaroor sy eie saak gemaak het in die bestaan van 
Jesus Christus. God het mens geword en sy Seun het aan die kruis gesterf. Van daar gedink, vind daar in die feit dat die mens 'n doener van sonde word, kennelik vir God self 'n bedreiging van sy totale werk, sy ganse geskape wêreld plaas, ondanks die magteloosheid van die sonde. Die mens se teenstand en teenspraak, sy goddeloosheid en onmenslikheid, sy hele vergryp teen God is onloënbaar geen kleine, maar onmeetlike groot ongerymdheid, dwaasheid, absurditeit wat God self na die strydperk roep. Sonder ons wat in daardie absurditeit verval het, wil God nie God wees, hoog en majesteitlik nie. Voor God is hierdie dwaasheid as ons daad só gewigtig, só ryk aan gevolge, só gevaarlik, dat 'n blote skikking en regstelling in die algemene gang van sy wêreldheerskappy nie ter sprake is nie. Nou is dit so dat die kwaad nie 'n element van die gewone gang van die wêreld is nie, maar die duistere element is wat daardie wêreldloop sonder meer bedreig. Dit is die onkruid wat die vyand in die goeie saailand saai. Dit is die deurbraak van die chaos, die rewolusie van die nihilisme (ontkenning van alles wat bestaan), die einde is die tot niet maak van alle kreatuurlike bestaan. Die vraag is hoe 'n mens tot insig kan kom dat die sonde só ernstig en swaar is. Hoe dikwels is nie al gewonder oor die onbeduidenheid van die sondedaad soos Genesis dit beskrywe nie, en ook oor hoe elke mens in navolging van die eerste mense sonde doen. Ons het ook maar'n baie gematigde opvatting oor die erns en skade van sonde as 'n mens let op wat ons alles bedink om dit te voorkom of die uitwerking daarvan te besweer. Alleen van die kruis af kan die volle gewig van die sonde bepaal word. Dit is só groot dat God se liefde daarop net só kon antwoord en reageer dat Hy Homself in Jesus Christus oorgegee en prysgegee het. So het Hy die oordeel oor die sonde voltrek, dat $\mathrm{Hy}$, die Regter, Homself laat veroordeel het en die ou-mensvan-sonde in sy eie persoon laat dood maak het. Wat Jesus Christus gedoen het, het God self vir ons en in ons plek gedoen. Wie in Christus glo en in Hom sy eie en die Heiland van die wèreld erken, sal hulleself nie in die onskuld en geduld, nie in die gehoorsaamheid van Jesus Christus herken nie, maar in die mense wat hulle op Goeie Vrydag rondom Hom bevind het. Vir hierdie laastes het Christus in die dood gegaan en so met God versoen. Hy alleen het dit gedoen. Op die erkenning hiervan rus die navolging en gemeenskap van ons bestaan en doen met syne. Alleen deur geloof in Hom kan dit werklikheid word. Alleen deur God se genade kan daar verandering en nuwe lewe kom. Alleen só word ek gered. Deur God se genade beteken dat ek die verandering en nuwe lewe ervaar, of liewer, dit val my te beurt wanneer God in Jesus Christus vir my intree en in my plek handel. Alleen in Hom is daardie verandering en vernuwing en redding ' $n$ werklikheid. Ek kan self niks doen nie. Ek kan net glo dat 
daar en toe alles vir my gedoen is. Wie in die persoon van 'n ander gered is en juis net só gered kan word, is kenbaar in eie persoon 'n verlore mens. Só ken die mens-van-sonde homself. Die spieël van gehoorsaamheid van die Seun van God is die dwang, of liewer die bevryding tot hierdie erkenning.

\section{WAT IS SONDE?}

In die voorgaande is die plek aangedui van waar die mens-van-sonde geken en beoordeel kan word. Nou bly die vraag egter: wat is sonde eintlik? Hoewel nie dit alleen nie, moet vanuit die leer oor Christus gesê word dat sonde altyd ook hoogmoed is. Dit is dieselfde wat ook al genoem is: die mens se ongehoorsaamheid, sy ongeloof. Sonde is eintlik niks anders as ongehoorsaamheid en ongeloof ten opsigte van Jesus Christus in wie God sê wie Hy is en wat Hy wil. God is ook God in die nederige gestalte van 'n mens en Hy doen dit in die vryheid van sy liefde om op hierdie wyse die mens te help en te red. Daarom kom Hy in Christus in die gelykheid van die sondige mens. Die mens handel egter teenoorgesteld tot die genade van God wat in Christus werklikheid geword het. Die mens is daardie wese wie se handelwyse God se handelwyse in Jesus Christus teenspreek sodat dit lyk of God en mens in teenoorgestelde rigtings beweeg. Teenoor God se deemoed, God se groot nederigheid, staan die mens se hoogmoed. Hierdie groot menslike wanorde word onder vier aspekte behandel.

- Die Woord het mens geword soos ons. Dit is die Goddelike deemoed en die betoning daarvan is die groot en onbegryplike hoè en wonderbare Godsdaad: God word en is soos ons. Ons egter vir wie God so God is, ter wille van wie hierdie Godsdaad geskied, ons wil soos God wees, wil self God wees. Onmiddellik moet die totale onmag van hierdie onderneming onderstreep word waardeur sy inherente nietigheid openbaar word. God word en is mens. Om soos ons te wees is werklikheid. Dit is die daad van Hom wat vry en magtig is om dit te doen. Dit is die geweldige uitvoering van sy ewige raadsbesluit: triomfantelike, onbetwisbare, onherroeplike gebeurtenis. Die mens egter wil hom net verhoog, wil net soos God wees. Hy sal dit nooit word en nooit wees nie omdat hy geen vryheid en mag daartoe het nie. Hy mag dit 'n lang tyd besluit, maar daar kom tog niks van nie. Hy val altyd maar weer op homself terug en bly maar net mens. Daar is niks teenstrydigs of ongrymds in dat God mens word en is nie. Dit weerspreek nie die begrip 'God' nie, maar vervul dit juis. Dit is God se heerlikheid wat só openbaar word. Dat die mens God wil wees is sonder meer iets teenstrydigs en ongerymds. Dit weerspreek die begrip 'mens'. Dit breek so 'n begrip op. Die mens word 'n onmens as hy so iets wil. God verander nie as Hy mens word nie. Hy bly nog Skepper. Die mens moet homself 
egter verander om God te word. Geen hoop of vrees dat dit hom ooit sal geluk nie. Tot sy heil is daarvoor gesorg dat die mens sy grense nie kan oorskrei nie, al storm hy ook daarop af. Alleen sy onmag om homself te oorskrei, sal aan die lig kom wanneer hy inbreuk wil makk op God se terrein. En omdat hy dit nie behoort te wil nie, sal slegs sy skande openbaar word.

Hoewel dit 'n magtelose onderneming is van die mens om soos God te wil wees, verander dit niks aan die feit dat dit in sy totale verkeerdheid wel gebeur. So 'n handeling van die mens het geen grond nie. Dit kan van geen plek af afgelei of verklaar word nie. As die mens hierdie weg kies, doen hy wat hy as goeie skepsel nie kan doen nie omdat hy geen vryheid daartoe het nie. Hy maak homself net onmoontlik, maar dit doen hy dan ook. Hy is God se goeie geskape wese wat die bose, die sondige doen. Dat God soos ons word, is die daad van sy deemoed. Daarteenoor stel die mens sy hoogmoed deur soos God te wil wees. Die absurde, dwase, ongerymde wat die mens doen wanneer hy soos God wil wees, kan nie gefundeer word nie. Dit het geen grondslag nie. Dit kan net beskrywe word.

Dat 'n mens soos God wil wees, is eerstens vir jouself verborge. Daarom moet dit vir jou deur God se Woord gesê word. Daarvoor is geloof nodig, sodat dit vir jou gesê kan word. Dat 'n mens soos God wil wees, is daardeur vir jou verborge deurdat jy maar net op 'n bepaalde wyse jouself wil wees. Jy wil mens wees, geen verantwoordelikheid teenoor enigiemand nie, geen inspraak of aanspraak van iemand anders. Jy beskik oor jouself en is mens vir jouself. Hoogmoed en die sonde om soos God te wil wees, lè nie voor die hand nie. Sou dit nie die hoogste deemoed, nederigheid, kon wees as 'n mens maar net mens wil wees, onafhanklik van ander, vir jouself lewe, maat en wet, begin en einde vir jouself wees. Skynbaar is dit tog geen oortreding op 'n ander se terrein nie. Dit is niks anders as selfhandhawing nie, net 'n groot tevredenheid met jouself. God hoef tog deur dit alles nie ontken te word nie. Daar kan gevra word of God nie die mens daartoe geskep het om oor homself te beskik en vergenoeg met homself te wees nie? Wat is verkeerd daarmee? Dit lyk tog glad nie of die mens soos God wil wees nie, self God wil wees en daardeur sondaar word nie. Dit lyk eerder of die mens in alle beskeidenheid die regte ding doen, die wil van God reg verstaan en sy menswees korrek vervul. En tog het ' $n$ mens hier met die ergste verhulling te doen, maar wat wesenlik deur hierdie verhulling plaasvind, word tog nie bedek nie, soos uit die volgende blyk:

* Juis dit is die vergissing van die mens omtrent homself dat hy reken hy kan homself in sy selfgesentreerdheid liefhè, kies, handhaaf, onderhou en daarin ware mens wees. Maar juis daarin vergis hy hom met homself, want die 
mens is nie geskep om op homself gerig te wees nie, oor homself te beskik, op homself gesentreerd te lewe nie - nie die individu nie en ook nie die gemeenskap nie. Die mens is juis bestem om in die verbond met God te bestaan, om van sy genade en in verantwoordelikheid voor Hom te lewe. 'n Mens is mens omdat jy van God af kom en Hom tegemoet gaan. Kies 'n mens die ander wyse van bestaan, op jouself gerig, verloor jy wat jy wil red en word jy onmenslik.

* Ook die dwase strewe om soos God te wil wees waarmee die mens in sy vergissing oor homself besig is, verhul wat werklik plaasvind. Hierdie strewe is immers geen duidelike waansin, geen aanwysbare groot onsin en grootdoenery nie. Dit is wel getuienis dat die mens glo hy durf homself objek van selfgerigte liefde maak. Wat sou die sin dan daarvan wees dat hy benewens sy selfgerigte lewe waardeur hy reken dat hy vir homself bron en rigsnoer kan wees, God tog nie ontken nie, miskien reken dat hy met erns in Hom glo, of hom miskien inbeeld dat hy aan God sy goedbedoelde en hoogste eer bewys deur so 'n selfaanvaarding en optimisme oor homself. Wat die hoogste vir die mens is, dit is vir hom sy God. As die mens vir homself die hoogste is, dan is hyself vir hom God. Die enigheid, uniekheid en selfgenoegdoening wat die mens vir homself toeëien, is nou eenmaal net eie aan God. Om liefgehê te word ter wille van homself, kom Hom alleen toe. Daarom beroof die selfgesentreerde mens wat net om homself draai vir God deur vir homself te neem wat net aan God toekom. Hy doen dit om homself te versier, om soos God te wees, self God te wees. Daar vind 'n gekke omruiling plaas. Ons het gesien dat dit nooit kan slaag nie, dat die mens nooit soos God sou kon word nie. Hy kan dit net wil wees. Hy kan net dink en handel soos een wat reken dat dit hom kan geluk. Wat die mens kan bereik, is net om hom onbeskaamd te verset teen die grense wat vir hom as mens gestel is en sodoende van hom 'n valse God te maak. Maar dit doen hy dan inderdaad. Sodoende vereer hy homself heimlik, en só tree hy dan ook tevoorskyn, nie sonder om ander te bedrieg nadat hy homself reeds bedrieg het nie. Die oortreding op ' $n$ ander se gebied word werklikheid. Dit vind plaas in die verhulling waarmee dit gebeur.

* Nie net ten opsigte van homself nie, maar ook ten opsigte van God vergis die mens hom. Hy maak van God'n wese wat selfgesentreerd, net op Homself gerig is. Dit is waar, God is in Homself, van Homself en deur Homself, enig en uniek, maar Hy is tegelyk ook vir ons, wat as Vader ons van altyd af liefgehad het in sy Seun en Hom van altyd af deur die Heilige Gees na ons gewend het. In hierdie keuse van homself by God en sy genade verby, kies 
die mens inderdaad die in sigself nietige. Soos Luther gesê het, maak hy God sodoende tot 'n duiwel. Want as daar' $n$ duiwel is, moet hy identies wees met ' $n$ absolute wese wat net op homself en sy eie heerlikheid gerig is. Die duiwel kan net as 'n onafhanklike on-wese beskryf word. Daarvoor is gesorg, nie deur die mens nie, dat hy nie sal verduiwel en sy natuur nie sal verander in die van 'n on-wese nie. Hy kan sy natuur wat oop is van God af en na Hom toe, wel verloën, maar nie kwytraak nie. Dit neem egter nie weg dat die mens wat hom op daardie 'valse' god rig, sy siel aan die duiwel verkoop en hom op 'n terrein begewe waar hy reddeloos sal wegsink as hy nie daaraan ontruk word nie.

- Dit is dan hoe die mens in sy onversoendheid, in sy afkeer van God, in sy hoogmoed uitsien, die mens wat God in Christus met Homself versoen het en na Homself toe omgekeer het. Tot die mens wat só diep geval het, het God in Christus afgedaal. God ken ons en Hy weet wat ons gedoen het. Op so 'n lewensvreemde en lewensgevaarlike poging van die mens om soos God te wil wees, het God met sy genadige en oorwinnende daad geantwoord deur self soos die mens te word. Die Woord het mens geword.

- In sy versoeningsleer beskrywe Barth die bestaan en werk van Jesus Christus as die Heer wat 'n kneg geword het. Sy heerskappy bestaan daarin dat Hy Hom onderwerp. Sy ryk is diens. Christus het kneg van alle knegte geword. Dit is die deemoed van God se daad wat vir ons almal plaasgevind het. Die mens egter vir wie God só God is, is presies omgekeerd, die kneg wat Heer wil wees. Die nietigheid van hierdie onderneming van die mens lè voor die hand. Die werklike Heer wil nie net kneg wees nie, maar word dit ook sonder enige voorbehoud. Nêrens vind 'n mens 'n selfverpligting en onderwerping só werklik as wat in Jesus Christus plaasgevind het nie. Orals waar so iets gebeur, steek daar 'n mate van terughouding en teenstand in wat die werklikheid daarvan problematies maak. Jesus, die Heer, doen dit egter met volmag. Wat Hy wil, gebeur: Hy word kneg. Die mens vir wie Hy dit doen, wil net heer wees. Die volmag waarmee hy die ooreenstemmende dade en gedagtes wil gebruik, is op 'n slinkse wyse bekom, en daarom oneg. Hy sou, ooreenkomstig sy skepping en sy behorenheid tot die verbond, met God as sy magtige Heer in vrede kon lewe, en as vriend van God, ook as kneg magtig kon wees en saam met Hom heers. Maar deur vervreemding van God en selfgerigtheid gee hy die volmag daartoe prys. Hy dink en handel nou nog net as sy eie skaduwee, asof hy dit sou hê. Hy kan nog net groot meneer speel. Wat hy bedoel en soek, kan hy nooit verwesenlik nie. Hy wil dit alles, maar speel slegs 'n rol, asof hy dit doen. In die lig van wat Christus vir hom gedoen het, is hy as sodanig geopenbaar en aangekla. Daar is 
geen grond aan te voer waarom dit so met hom gesteld is nie. 'n Mens kan hom alleen in hierdie lig beskrywe.

Ook hier moet 'n mens aandag gee aan die vermomming waarir hy dit is. Die hoogmoed en die wil tot realisering is ook hier nie voor-die-hand-liggend nie. Wat hier sigbaar word, kan ook die hoogste wettige gebruik van mag wees wat aan die mens verleen is: die mag van sy kennis, oordeel en vermoëns waardeur hy hom in superieure afstand teenoor homself en die wêreld rondom hom stel. Dit is waar, dit sou ook die daad van deemoed kan wees, die diens van die ware kneg, verrig in ware godsvrug en nie as loëning van God nie. Die kwaad sal wel op sy hoede wees om hom ooit so voor te stel. Om hom te kamoefleer sal dit veeleer weet hoe hy hom nie net in die kleed van onskuld nie, maar ook van deugdelikheid moet vermom. Om dit as sonde aan die lig te bring, sal die Woord van God altyd nodig wees. Juis die vrymaking van die mens, sy selfverheffing van $\mathrm{kneg}$ tot heer, skyn immers in die eerste plek niks anders te wees as sy onvermydelike mondigwording nie en in sovêr, die legitieme vervulling van sy menswording.

Dit is weer so dat die mens in plaas van kneg, heer wil wees, hom allereers in die swaarste vergissing dompel ten opsigte van homself en die noodlottige serlfvervreemding en selfvernietiging waarin hy hom bevind. Hy is juis onder waar God bo, tweede waar God eerste, afhanklik waar God soewerein is, en wel s6, dat in en onder hierdie ordening hy op God se vrye, onvoorwaardelike en volle genade aangewese is. Juis in hierdie ordening is hy vry en kan hy sy eie wese heerlik realiseer. Om aan God verkleef te wees is vir hom die beste, waarteenoor daar geen betere is nie, geen groter eer of waarde nie. Juis as God se kneg sou hy kon en sou hy wesenlik en volledig mens mag wees in die sin van sy geskape natuur, en in vervulling van sy bestemming tot deelgenoot in die verbond met God, selfs aan sy heerskapy deelneem. As hy teen hierdie ordening in verset kom en daaruit wil tree, is hy niks anders as 'n nar en in stryd met homself. Wat hy oneindig meer ag, is oneindig minder. As hy dink dat hy homself verhoog, stort hy in die diepte. Deur daardie ordening is sy vryheid wel begrens, wat hy is, wat hy kan, wat hy behoort te doen en wat hy mag word, maar dit is ook beskerm en gewaarborg deur daardie ordening. Om dit te versmaai kan net tot sy verderf geskied. As hy as kneg in opstand kom, word hy 'n slaaf.

Dit help niks dat die mens alles wat hy onderneem, anders verklaar nie. Teenoor die nugtere waarheid is dit niks anders as rebellie nie. Rebellie beteken egter wanorde en wanorde chaos. Al noem die mens die aangeleentheid altyd weer sy ware menswording, al dink hy altyd die narregedagte dat sy doen daartoe kan lei, feit bly, dit deurbreek en ontsier die verhouding tussen 
Skepper en skepsel, God en mens wat ten grondslag van die verhouding van alle geskape bestaan lê. Dit word omgekeer in 'n soort poetsbakkery waardeur alles wat onder is, skielik bo word. Dit word 'n skynwêreld. Dit kan nie anders nie dat die mens wat self baas wil speel, nou ook mag oor sy medemens probeer kry. Dit is die begin van die magstryd tussen vorke, individue, klasse en stande met wedersydse oordeel sonder enige genade. Hierdie chaos wat ontstaan, beteken die aanbreek van die opposisieregering van die radikale kwaad, die teenoorgestelde van God en sy werk. Dit is die onbeskaamde begin van 'n nagemaakte bestaan wat die einde van alle egte bestaan tot gevolg het, al kry dit ook die oorhand. $\mathrm{Al}$ is die verhulling in hierdie rebellie ook hoe skitterend, moet dit val, want dit gaan in daardie onderneming van die mens om die onherstelbare slegte, om ' $n$ bestaan wat as sodanig net ontken en afgewys kan word.

Agter hierdie onderneming van die mens staan die ontsettende vergissing ten opsigte van God. Dit is eenvoudig net nie waar nie dat God so ' $n$ Heer is teen wie 'n mens jou kan stel en sy plek wil inneem nie. So iets maak geen sin nie. Dit is net nie waar dat die mens enigsins verdruk kan voel omdat hy kneg, slaaf, van hierdie Heer is nie. Van die begin af is God die genadige teenoor die mens, wat die heilsame nie vir Homself opeis nie, maar dit ook vir die mens uitdeel. Meer nog, Hy is nie net Heer nie, maar in die volheid van sy openbaring word Hyself ook skepsel en mens en dus kneg, tree Hy naas ons en onderwerp Homself aan wat van ons verlang word. As 'n mens God se heerskappy beny en daarna jaag, storm jy by Hom verby in die leegheid in. Hierdie derde punt, die vergissing oor God, is weer eens die beslissende wat al die ander tot gevolg het: die totale ontkenning van God.

Dit is hierdie mens, die rebel, wat God in Jesus Christus met Homself versoen het. Hierdie mens is ons almal. Hoogmoed is te swak om hierdie gesindheid te beskrywe. Grootheidswaan sal 'n beter beskrywing wees. In teenstelling tot hierdie menslike grootheidswaan het God geantwoord deur Homself in Christus Jesus te verneder en gehoorsaam te word.

- Deur nogeens uit te gaan van die bestaan en werk van die Heer wat dienskneg geword het, vestig Barth vervolgens die aandag daarop dat Jesus Christus ons almal aangekla het deurdat Hy die ganse beskuldiging teen ons en alle mense en elkeen afsonderlik, 'n saak gemaak het wat Homself aangaan en raak, in plaas daarvan om dit, soos dit hoort, teen ons te rig. Terwyl Hy in ons plek tree, het Hy God onvoorwaardelik in die gelyk gestel teenoor Homself as draer van ons skuld en ons vonnis. Hy was die Goddelike regter wat die regverdige vonnis oor ons voltrek het, op so 'n wyse dat Hy Homself laat oordeel en teregstel het, dat wat welverdiend met ons moes gebeur, in sy Persoon gebeur het sodat ons 
tereggesteldes in Hom mag wees. Dit is die deemoed van die Goddelike daad wat in Jesus Christus vir ons plaasgevind het. Die mens vir wie God só in Jesus Christus ontmoet, vir wie God 'n broer word om dit te doen, is in direkte teenstelling met die een wat hom in die ongelyk stel deurdat hyself regter wil wees in plaas daarvan om God die reg te gee teenoor homself.

Ons begin deur vas te stel dat dit 'n ydele, magtelose en tevergeefse onderneming is, bestem tot mislukking. Die ware regter wil nie net aankla, oordeel en vonnis nie, maar hy doen dit ook. Omdat Hy volgens God se barmhartige keuse vir ons oorgelewerde, gekruisigde en gestorwene was, is en sal wees, en omdat Hy Hom gebuig het onder die gerig wat ons moet tref, en omdat $\mathrm{Hy}$ as gebuigde onder hierdie gerig leef en sal leef, het die gerig oor die wêreld plaasgevind.

Tussen goed en kwaad is op alle gebiede messkerp onderskei. Alle mense, in hulle openbare sowel as verborge bestaan en handelinge, is in die lig van hierdie onderskeiding geruk. Alle geskape tyd, alle mensegeskiedenis, ook die enkelinge se lewensgeskiedenis in hulle reg en onreg, is reeds van God af deursien en dit loop die openbaring van die gerig wat in Hom plaasgevind het, tegemoet.

Die mens wíl egter net oordeel. Hy dink dat hy op 'n hoê troon sit, maar hy sit op 'n kinderstoel en blaas sy klein trompetjie en slaan met sy klein swepie en wys met sy vingertjie verskriklik ernstig hiernatoe en daarnatoe, sonder dat iets wesenliks gebeur. Hy kan maar net regter spéél. Sy onderskeiding tussen goed en kwaad, reg en verkeerd, is amateuragtig en 'n knoeiery. Hy kan net maak asof hy daartoe in staat is. Dit hoef nie so te wees nie. Hy kon in vrede met God, van homself seker wees, die regte in vryheid doen en die verkeerde in dieselfde vryheid vermy, as hy God van die begin af maar sonder vraag of voorbehoud gelyk wou gee, sy beslissings oor hom wou aanvaar en hom daarna voeg. Maar deur sy teenbeweging deur self regter te wees, stel hy homself reeds in die ongelyk en probeer hy die onmoontlike wat hy nooit sal reg kry nie.

Hy wil egter regter wees en sodoende skep hy werklikhede. Die geskiedenis van elke mens is in werklikheid die geskiedenis van sy beterwetery. Nuwe en teensprekende beterweterye is die geskiedenis van die mensheid. Om as mens te lewe beteken om op een of ander wyse op pad te wees om 'n maatstaf te vind om eie en ander dinge te beoordeel. Dit lei tot allerlei botsings en stryd, vreugdes, teleurstellings en frustrasies. Uiteindelik is die vraag of dit alles die moeite werd is. Al gebeur daar niks wesenliks deur die uitoefening van die mens se oordele en veroordelings nie, ontstaan daar tog 'n pynlike, en in sy wanordelikheid aanwysbare werklikheid: die opbou van 'n verduisterde, ver- 
skeurde en beduiwelde wêreld. Die mens wat op onverklaarbare wyse uit die vrede met God en met homself geval het, wat op sy kinderstoeltjie sit en wat hy dink 'n troon is, skep werklikhede waarvan die bestaan onverklaarbaar is en geen fundering het nie, maar wat net in sy feitelikheid beskrywe kan word.

Die verhulling van die mens se hoogmoed in hierdie geval is merkwaardig. Wat hier sigbaar word, is op die oog af ver verwyder van iets slegs. Immers, wat is beter en waardevoller as dat die mens tussen goed en kwaad kan onderskei? Wat sou hy wees as hy van hierdie moontlikheid nie gebruik maak nie? Moet in die uitoefening van hierdie moontlikheid om te oordeel, nie die mondigheid van die mens erken word as menslike taak nie? Waarin is die kwaad dan geleë as dit daadwerklik gaan om teoretiese en praktiese onderskeiding tussen goed en kwaad en dus die veronderstelling vir die doen van alle goed en die laat van alle kwaad? Anders as deur God se Woord sal die kwaad in hierdie edelste gestalte inderdaad nie aan die lig gebring kan word nie.

Die verhulling of verberging is hier besonder groot. ' $n$ Mens moet jou verbaas dat in die Christelike kerk nie méér aanstoot geneem is aan die feit dat die begeerte na kennis van goed en kwaad so uitdruklik as dié sondige begeerte voorgestel word, wat vir die hele menslike geslag tekenend en noodlottig geword het. Vir die teorie en die praktyk van die Christelike Etiek (die wetenskap wat die menslike handelinge volgens Bybelse norme bepaal), sou dit onberekenbare gevolge gehad het as ingesien is dat wat in Genesis 3 vermeld word, nie die fundamentele gawes van God aan die mens is nie. Die pantser waaragter die werklike kwaad en sonde, die menslike hoogmoed, hom hier verberg, is die grootste van alle kamoeflasie.

Dit mag ons nie verhinder om in te sien nie dat die begeerte na hierdie kennis om self regter te wil wees, 'n groot misverstand van die mens omtrent homself beteken en dat hy hom met hierdie begeerte net kan verwar en vergis. Tussen goed en kwaad, reg en verkeerd, orde en wanorde moet inderdaad gekies word, daar moet dus 'n oordeel plaasvind. Die bestaan van wêreld en mens staan en val daarmee dat in hierdie groot alternatief, net die een of die ander kan geld. Daar is geen plek vir kompromie, vrede en balans nie, maar beslissing en keuse. Sonder seëvierende verdediging van die goeie en regte en ordelike, en die afwys van die teenoorgestelde, kan niks bestaan nie en moet vernietiging in ons aardse werklikheid tree. God se verhouding tot die bose, die onreg, die wanorde en die nietige, en derhalwe hulle bestaan, berus op God se beslissing, realiseer in God se oordeel, rus dus op God se kennis van daardie alternatiewe. Wel op sy oordeel, sy kennis, sy beslissing. Dit alles is Goddelike en nie menslike werk nie. Die mens kan hom slegs as getuie van God op die bodem van 
daardie werk stel wat deur God gedoen is, en kan hom alleen aan Gcd se oordeel en beslissing hou en aan die openbaring van God se kennis en wete. Hy lewe daarvan dat wat hierdie saak betref, God self die nodige weet en doen, dat God die groot krisis, groot oordeel is waarsonder hemel en aarde en die mens geen oomblik kan bestaan nie. Ek is vrye mens, vry-denkend, vry-handelend en beslissend, as ek dit daarby laat. Dan doen ek die goeie en die regte en ek handel ordelik, as dít vir my die alleen moontlike, die alleen vanselfsprekende is, dit wat God vir my geskies het. Wanneer ek hierdie goddelike keuse bely, sonder om dit te kontroleer of in my eie keuse in te voeg, dan doen ek goed en reg. As my eie beslissing die na-voltrekking van God se beslissing is, dan is ek 'n vrye mens. As dit vir my te gering is, en ek self beslissings wil neem terwyl God reeds besluit het, dan is dit 'n dwase selfoorskatting asof ek die een is wat bokant daardie geweldige alternatiewe staan en dat ek self die Atlas is wat die wêreld dra. So 'n begeerte beteken die uittrede uit die gehoorsaamheid. Hierdie begeerte beteken dat die mens onmiddellik sy vryheid onherroeplik verloor. Hy het die beskermende vrede van die vaderhuis verlaat. So 'n begeerte beteken die ergste vernedering van jouself.

As die mens hierdie keuse doen, vind die saaklike boosheid plaas. Natuurlik bedoel hy daarmee nie net om nie die verkeerde te doen nie, maar om die goeie, noodwendige, die vereisde te doen en derhalwe die beste. In hierdie gestalte van die sonde is daar skynbaar geeen sweem van luiheid, ligsinnigheid en vuilheid nie. Inteendeel hier toon dit sigself in roerende erns, omhul met die glans van diepste verantwoordelikheid, strengste pligsbesef en strydlustige deug. As regter oor goed en kwaad wil die mens so te sê saam met God in die bresse tree vir die kleine en grote wêreld teen die aanslag van die chaos, die wanorde en die slegte. Die ontsettende werklikheid is dat hy hom daarin juis vergis, dat hy dit om elke prys moet laat vaar, omdat hy juis daarmee die hel loslaat. Waarom? Omdat hy juis nie die een is wat daartoe in staat is nie en omdat sy opmars juis die teenoogestelde bewerk as wat hy bedoel. Omdat jy en ek ons hier beweeg op 'n terrein waarvoor ons nie opgewasse is nie, het die duiwel ons reeds van die begin van ons opmars teen die kwaad oorwin en veg ons juis aan sy kant. Ja, ons is die groot vegters op die duiwel se front. As ek reken dat ek self weet wat reg is, kies ek reeds die verkeerde en as ek self in die werk wil stel wat ek gekies het, doen ek reeds verkeerd. As ek myself as die een wat reg is teenoor ander stel en as die groot krisis hulle wil oorval, stel ek my teenoor hulle onmiddeilik in die ongelyk en doen ek hulle 'n onreg aan. Hierdeur verbreek ek gemeenskap met die ander. In gemeenskap met mekaar kan ons slegs leef as ons almal buig voor die hoë reg wat van bo af in God se Woord en ge- 
bod, en nie uit onsself, deur die oordeel van die Heilige Gees tot ons kom. As ons oë oopgaan vir ons eje oordeelsvermoë, word ons blind vir reg en onreg. Dan begin ons droewige morele lewe wanneer ons onsself vandag vryspreek, terwyl ons deur ons ware Regter lank reeds veroordeel is. Môre veroordeel ons onsself oor sake waarvan God ons lank reeds vrygespreek het.

Ten grondslag van alles hier lê ook 'n groot vergissing ten opsigte van die Godsbeskouing en Godsbegrip, en wel in drieërlei opsig:

Beslissend ook hier is dat God in die uitoefening van sy regtersamp juis nie in daardie vals-goddelike hoogte van 'n onbedekte oppermag troon nie, waarin die mens in sy dwaasheid Hom moet sien om Hom te beny en reken dat hy hom tot hierdie God moet verhef om waarlik mens te kan wees. God is wel die Hoê God, wat weet van goed en kwaad en wat in roerende erns tussen beide skei. $\mathrm{Hy}$ is die regte vriend en helper van elkeen wie se bestaan aan sy verkiesing, aanvaarding en skeppende aktiwiteit te danke is en juis daarom regte en egte bestaan is. As sodanig is hulle die regte teenstanders en vyande van die Nietige wat vreemd is aan God se wil, en derhalwe deur Hom verwerp en ontken. Maar in hierdie openbaring en verdediging van sy eer en heerlikheid is God nie selfsugtig en sodoende met die bevrediging van sy eie behoefte besig nie. God het as God nie nodig om homself te kies en te omskrywe en om Hom in die groot teenstelling tussen die bestaande en die nietige te stel nie. Hy het nie nodig om te kies vir die bestaande en dit te verdedig nie, en die nietige om dit teen te staan en te verwerp nie. Daar is vir God gee.n nood waarom Hy regter van die wêreld moet word nie. Dit is alleen die skepsel wat in nood verkeer en wat Hom as regter nodig het. Dit is vir ons wat Hy in onbegryplike barmhartigheid aanneem. As God Hom nie tussen ons en die niks stel nie, is ons verlore. Hy doen dit in Jesus Christus. Hy sorg vir sy eer deur ons van die bose te bewaar. Aan die handhawing van hierdie eer hang nie God se bestaan nie, maar ons s'n. Ons is egter dwaas genoeg om God dit te betwis.

* God sorg egter vir sy eer en ons behoud inderdaad. Hy weet wat goed en kwaad is, ongetwyfeld. Hy stem hrér toe en help, om dáár weer nee te sê en te versteur. Hy doen dit egter nie as die oorwinnaar nie. Die mens reken dat hy Hom só moet sien wanneer dit met hom in orde kom. Dat God Hom beskermd op die grens tussen goed en kwaad stel, beteken dat Hy Hom daartoe oorgee om Hom saam met sy skepsel in daardie teenstelling te stel. Hy laat Homself deur die Nietige problematiseer, beledig, aanveg om sodoende die oortreding, skuld en nood van sy skepsels ter harte te neem. Uiteindelik neem hy die vonnis waarin ons deur ons vervlegting met die 
kwaad en die Nietige moes verval, op Hom. In wat Hy doen en is as regter, het Hy geen lus, maar dit is diepste leed wat Hy op Hom neem. Van hierdie leed, waarteenoor ons leed net 'n skaduwee is, leef die wêreld.

* God wat sy regtersamp só aanvaar en uitvoer, het geen kontrole of steun nodig nie. Om dit met ons gehoorsaamheid te betuig, is ons regmatige deel, dit is 'n saak van ons menslike vryheid, waarde en heerlikheid. Oor God se geregtigheid hoef ons ons koppe nie te breek nie. Teenoor Hom kan alle menslike wysheid, vasberadenheid en daadkrag slegs daarin bestaan om syne met volhardende daad na te volg, nie op eie weë nie, maar streng op sy weg. As ons naas Hom wil tree, word wat ons reg wil doen en wat ons wil vermy, juis dat ons die goeie vermy en die verkeerde doen.

- S6 sien die mens dan in hierdie derde siening oor hom uit, die mens wat God in Jesus Christus met Hom versoen en na Homself omgekeer het. Ons elkeen is hierdie onbevoegde en daarom onregverdige regter. Ek is hierdie hoogmoedige en daarom sondige mens. Na my toe het God in sy versoenende genade neergedaal. Wat God in Christus vir ons gedoen het, het betrekking op ons hoogmoedige avontuurlike dade: die straf wat vir ons vrede bring, het Hy op Hom geneem.

- Om die mens se sonde as hoogmoed te leer ken, begin Barth nogeens by die bestaan en daad van Jesus Christus, wat as die Seun van God - en daarom self God - in sy diepste vernedering aan die kruis geroep het: My God, my God, waarom het $\mathrm{U}$ my verlaat? Hoewel Hy Seun van God was, sterf hy as ware, wesenlike mens. Hy word begrawe en rus in die graf - Hy die ewige, lewende, almagtige God in die persoon van hierdie mens, alleen op die vrye genade van God, die Vader, aangewese, op sy onverskuldigde vryspraak, op sy onverdiende erbarming, met net hoop op sy leweskeppende mag. Daarheen het Hy Hom begewe om ons plek in te neem, om die gerig oor ons sonde te deurly, om ons verlore saak te behartig. Ja Hy het tot in die diepte van volledige hulpeloosheid gegaan, tot die nie te wil of te kan beskik oor die hulp van God. Dit is die diepte hierdie waar Hy behalwe die Nietige, niks onder Hom of naas Hom nie, en behalwe God niks voor Hom of bo Hom gehad het nie. Inderdaad die Nietige, in sy onpeilbaarheid en oormag, en net God as die Een in wie se hand $\mathrm{Hy}$ Hom sonder voorbehoud oorgegee het, Hy die mens wat self God se Seun was. Dit doen Hy vir ons. Dit is God se deemoed, God se groot nederigheid, wat vir ons God se daad geword het in Jesus Christus. Direk in teenstelling tot God wat Hom verneder het om aan mense gelyk te word, het die mens nog altyd gedink, en sal hy altyd dink dat hy homself kan help en terwyl hy daarmee besig is, reken dat hy aanspraak het op God se hulp. 
Maar hierdie sienswyse is onhoudbaar omdat dit slegs 'n sienswyse is. Jesus het nie enige sienswyse gehad toe Hy die kruisdood tegemoet gegaan het nie. Aan die begin van hierdie weg was Hy reeds gehelp in die raadsbesluit van God, wat vir Hom en vir ons almal verborge is. Maar die raadsbesluit het vir Hom duidelik geword deur die opwekking uit die dood. In God se raadsbesluit is $\mathrm{Hy}$ geregverdig, het God Hom in vrye erbarming aangeneem, word Hy deur God se skeppersmag in die onverganklike lewe saam met God geroep: Hy, wat alhoewel Hy oor die mag beskik het, homself nie gehelp het en op God se hulp geen aanspraak gemaak het nie. Juis hierdie hulpelose mens was die almagtige God. Die mens wat nie hulpeloos wil wees nie, maar dink dat hy homself kan help, reken dit tevergeefs. Hy dink dit net uit en prent hom dit net in. Al weet hy nie hoe nie, sal hy wel 'n weg vind, want weë is daar nog altyd gevind. As hy daarby sy kant bring, sal God se hulp gewis aanwesig wees. Maar dit is alles net inbeelding. Dit is waar dat' $n$ mens jou innerlik en uiterlik met baie kan help en dit ook moet en behoort te doen. Die vaardigheid en gawes daartoe kom van die goedheid van die Skepper en sal altyd daar wees. Maar dit het sy grense en eendag eindig dit en verder kan geen mens hom meer help nie. Om te dink dat 'n mens jou met iets anders kan help is heeltemal iets anders as om te dink dat jy jouself kan help, bewaar of red, vir jouself lewe, vrede en vryheid kan gee. Niemand kon dit nog en sal dit ooit kan doen nie. Die mens het geen staanplek van waar hy dit kan doen nie. 'n Mens staan bo baie dinge en kan soms baie magtig wees, maar nie oor jouself nie. Daarom kan hy homself nie help nie, ook nie saam met ander nie. Alleen van God se staanplek af kan 'n mens gehelp word. Ons vergis ons as ons dink dat die baie goeie dinge waarmee ons onsself behelp ook beteken dat ons onsself help. Teenoor jouself staan ' $n$ mens hulpeloos. Om te dink dat 'n mens jouself werklik kan help, is 'n onhoudbare sienswyse.

Nou lewe die mens egter met hierdie vergissende sienswyse inderdaad. Die geskiedenis van elke mens is die geskiedenis van sy groot en fantastiese poging om homself te help. Hy jaag en gryp so lank as hy lewe na hierdie en daardie. Hy strewe daarna en sloof hom af daarvoor met 'n onrus en hartstog wat onverklaarbaar is, gesien die innerlike waarde van die dinge waarmee hy homself wil help. Die rede waarom hierdie gesoek maar altyd voortgesit word, lê in die feit dat dit 'n valse sienswyse is en dat die mens telkens dink dat dit hom hierdie keer sal geluk om sy eie helper en verlosser te wees. Tot hierdie stand van sake behoort ook die funksie wat aan God toegeken word en die wyse waarop Hy aan die valsheid sal deelneem. Die mens se inbeelding om sy eie helper te wees, benodig ' $n$ hoër wese, so een wat hom in sy inbeelding sal versterk, 'n god 
wat hom sal help om homself te help. Sonder godsdiens of ' $n$ verminkte vorm daarvan, kan dit nie gaan nie. Belangrik is dat dit hier net om 'n god sal gaan wat hom in sy strewe na self-hulp nie in die weg sal staan nie, maar sal aanvuur, ondersteun en voorthelp. So 'n god is uiteindelik niks anders as die bonatuurlike ooreenstemming van die mens se wil nie. Aangesien die mens hom nie deur God wil laat help nie, bly vir hom niks anderș oor as om homself te help en van God sy handlanger te prober maak nie. Hiervoor is daar geen grond aan te voer nie. Die bestaan van die mens in hierdie verband kan net gekonstateer en beskryf word.

Ook hier moet die verhulling van die menslike hoogmoed ter sprake kom. In die gestalte van die mens wat homself wil help, kan dit hom op die voor die hand liggendste verstandelike oorwegings en die eenvoudigste opwellings van menslike instink beroep, soos: wie dink aan my? Wie is daar wat in my belangstel? Wie trek hom my lot aan? Wie help my as ek dit nie self doen nie? Of verder: wie weet wat ek nodig het, wie ken my besondere behoeftes as dit nie weer ekself is nie? Wie is verantwoordelik vir my, om my te help, wie my naaste, as dit weer eens nie ekself is nie?

- Dit lyk tog so ongerymd om iets slegs, ja die kwaad self daarin te sien as ek myself help.

Niks is egter ook makliker, as om die vraag na die verhouding van 'n mens se selfhulp tot die te verwagte Godshulp, uit 'n ander hoek te sien nie en te vra of dit nie dalk waar is, dat juis hy wat hom deur God laat help definitief die mens sal wees wat wel daaruit moed sal skep om homself te help. Kan die onweerlegbare waarheid nie dalk omgedraai en daarvandaan verstaan word, dat God juis die moediges help, dat die mens hom juis daarom laat help, dat hy na kragtige selfhulp gryp? Dit is dan veral die resultate wat 'n mens in eie lewe as vrug van flinke selfhulp en in die wêreld van die mensheid ook so dikwels waargeneem het, wat hier alles wil bedek. In ontelbare gevalle en op die wydste gebiede, het dit goed gegaan en geluk. Daar is verstandig gedink en doelgerig besluit. Daar is gewaag en aangepak en die gewensde resultaat het nie uitgebly nie. Daarmee saam voel 'n mens jou soos 'n ander mens: aangegryp, besiel, verhef, gedra. Tot so ' $n$ mate dat 'n mens altyd weer daaraan terugdink en jou van daar af weer bemoedig voel vir die toekoms. Beteken dit nie dat ' $n$ mens jouself nie net met dit en dat behelp het nie, maar jouself ook werklik gehelp het? En kan ' $n$ mens dit nie ook by baie ander waarneem nie? Waar is die kwaad onder die verhulling van so baie wat onbetwisbaar goed is? Laat ons maar toegee dat die kwaad vir ons ook in hierdie gestalte altyd onkenbaar sal wees en bly as dit nie van God se Woord af geken word nie. 
Dieselfde momente soos by die vorige gestaltes van hoogmoed, moet ook hier aangewend word:

- Die poging om self te help is ' $n$ vergissing van die mens oor homself. Die reg en noodwendigheid om jouself te aanvaar en aktiewe subjek van jou eie bestaan te wees, in verantwoordelikheid teenoor God en medemens jou bestemming te vervul, is normale veronderstellings van 'n mens se gehoorsaamheid. Dit is die normale ruimte om jou lewe in die verbond met God en in gemeenskap met jou naaste tot vervulling te bring. Wie beveel 'n mens om daaraan te twyfel dat jou vryheid daartoe in die vrye genade van God gegrond is? Hoe kom 'n mens daartoe om jou deur hierdie grense bedreigd, beledig en benadeel te voel? Wat dryf ' $n$ mens daartoe om hierdie grense nie dankbaar te aanvaar en te wees wat jy is nie, maar om hierdie grense te oorskrei en jou vryheid te wil soek in 'n droom van selfbegenadiging? Waarom dink die mens dat hy 'n veragter en vyand van God se genade en ' $n$ uitvinder van 'n beter genade moet wees, naamlik sy eie genade, om waarlik mens te wees? Ons staan hier voor 'n teenstrydigheid in die mens wat aan die een kant onbegryplik is omdat dit van geen kant af gefundeer kan word nie, en aan die ander kant vir die mens self onoplosbaar is omdat hy daaruit nie kan kom as hy eenmaal daarin verstrik geraak het nie. Daar kan slegs gekonstateer word dat die selfhulp waardeur die mens vir homself neem en gee wat hy slegs as geskenk van God kan kry, in sigself reeds ' $n$ teenstrydigheid is. Dit kan net 'n denkbeeldige nood of noodsaak wees wat 'n mens daartoe bring om jou afhanklikheid van God se genade en jou hulpeloosheid teenoor Hom as 'n belemmering of iets ergers te sien, en om in die dankbaarheid vir God se genade en jou hulpeloosheid teenoor Hom 'n belemmering of iets ergers te sien, en om in die dankbaarheid vir wat ons as hulpeloses van Hom ontvang ' $n$ skande te sien. Daar kan niks positiefs van verwag word en jou menslike situasie kan nie die geringste verbeter word wanneer ' $n$ mens jou van jou hulpeloosheid wil bevry en van die wet van dankbaarheid daarmee wil afsien, en jouself as eie helper benoem nie. Die teendeel is eerder waar: deur dit te wil, bring 'n mens jou immers eers reg in nood en skande. As ' $n$ mens jouself in eie hande wil neem, jouself wil bewaar, verdedig en wil red, verloor jy jouself, jou siel, jou lewe. Dat God ons genadig is, daarvan lewe ons. Na die mate dat 'n mens daarmee rekening hou dat God se genade die fondament is van jou innerlikste wese, ja van jouself, en in die mate dat elke gedagte totaal vreemd is dat ' $n$ mens self grond en fondament van sy bestaan is, na die mate leef ' $n$ mens eers werklik. Verag en verfoei 'n mens God se genade en jou totale afhanklikhheid van sy hulp, en aldus jou eie hulpeloosheid teenoor Hom, dan verag en verfoei 'n mens allereers onbewus jouself. Om jouself te probeer help is die verskriklikste vergissing. 
- Omdat jy hierdie dwaasheid begaan, doen jy sonde waaruit slegs die slegte kan kom. Die gehoorsaamheid sou die goeie gewees het, wat immers geen harde plig, geen onwillige onderwerping aan 'n vreemde gesag beteken nie, maar wat slegs vrye en vreugdevolle daad van 'n dankbare lewe kan wees. En dit veral omdat dit gaan volgens die wet en reël van die genade. Die titaniese mens, die groot en sterk, selfhelpende mens, kan as sodanig en sal net die verkeerde doen. En die heil, die geluksaligheid sou net die beskerming kon wees wat aan die mens in sy hulpeloosheid voor God ten alle tye onvoorwaardelik en afdoende verseker word. Die denkbeeldige nood en skande van die hulpelose mens voor God wat die selfhelpende mens wou ontvlug, word nou sy werklike nood en skande. Hy kan dit nie ontvlug nie. Vir hom wat nie hulpeloos voor God wil wees nie, bly niks meer oor as om sonder God, abstrak en volledig hulpeloos te wees nie. Dit beteken die Golgota, die Godverlatenheid van die ongehoorsaamheid, waar daar geen opstandingsmore anderkant is nie. Hy wou sy eie helper wees, en dit moet hy nou doen. Net aan homself is hy nou oorgelaat aan sy verbeelding, sy willekeur, sy denkbeelde, sy natuurlike bekwaamhede en vermoëns - hulle almal in diens van die uitsiglose taak waarvoor hulle nie geskik is nie, naamlik om die mens self te help. Juis dit beteken onbedekte hulpeloosheid, en omdat dit genadeloosheid is, ook heilloosheid. Want dit beteken om verstote te wees in 'n doolhof sonder uitgang, om 'n sware werk te verrig wat nooit voltooi word nie omdat dit altyd weer ongedaan gemaak word. Dit is soos honde in 'n honderesies wat 'n elektries aangedrewe kunshaas jaag wat hulle nooit sal vang nie. Behalwe dat dit hier nie om 'n hond en 'n wedren gaan nie, maar om 'n mens, die skepping van God, met wie God 'n verbond gesluit het, 'n mens met sy lewe wat enig en ongeëwenaard is. Behalwe verder dat die mens hier tegelyk die vervolgde en vervolger is, tegelyk 'n gek en die een wat homself 'n gek maak. 'n Mens kan vir jouself nooit genadig wees nie, al dink jy dat dit moontlik is en dit ook wil doen. As hy dink en probeer om homself te help, sal hy nie sy eie beste vriend, maar grootste vyand wees, 'n selfversorger wat homself nie goed nie, maar kwaad aandoen, ' $n$ aktiewe handelende persoon wat, noukeurig beskou, nie weet wat om met homself aan te vang nie. Hy is 'n 'verantwoordelike' persoon, maar omdat hy God as persoon teenoor hom kwytgeraak het, weet hy nie meer wat dit beteken as hy sy verantwoordelikheid wil laat geld nie. Juis daarom is hy bepaald nie 'n wese wat selfstandig dink, praat en handel nie, maar een van die baie toneelpoppies wat deur toutjies gemanipuleer word. Hy het saam met baie ander wat in dieselfde waan as hy verkeer dat hulle selfstandig is, reeds onselfstandig geword. 
Met die verlies van God teenoor die mens, gaan die verlies van die medemens teenoor hom gepaard. As selfhelper sal hy nie net vergeet dat hyself alleen gehelp kan word saam met sy medemens aan wie hy hulp verskuldig is nie. Hy sal hom teenoor sy medemens in 'n rojale isolering verplaas vind, so te sê agter die wande van 'n yskas wat hom hoogstens kan verander in 'n gevaarlike verdedigingsstelling met klein openinge na alle kante waardeur geskiet kan word. Teenoor sy medemens al hy voor alles ook nie weet hoe om homself te help nie. Hy sal juis nie in staat wees om 'n eie linie, 'n eie geslagslyn vas te hou soos hy graag sou wou nie, 'n karakter kry, 'n persoonlikheid word nie. Eerder sal hy prysgegee wees aan een of ander invloed en winde, tradisies en bewegings van sy omgewing. Sonder dat hy dit merk, sal hy 'n riet word wat heen en weer beweeg word, 'n blaar wat heen en weer gewaai word, nie iemand wat lewe nie, maar wat geleef word. 'n Individu wat homself wil help sal juis sy individualiteit kwytraak. 'n Gemeenskap wat uit sulke selfhelpers opgebou word, sal altyd besig wees om te ontbind.

- Ook hier is die groot misverstand wel die misverstand ten opsigte van God. Hy is nou eenmaal nie die God tot wie 'n mens vir selfhulp kan gaan nie. Dit is nie sinvol en juis nie. Dit kan ' $n$ mens alleen doen as jy God nie heeltemal in alles kan vertrou nie, of in een of ander opsig iets van Hom te vrees het. Daar is sommiges wat God sien soos die Grieke hulle oppergod, Zeus, indertyd gesien het, as 'n despoot, 'n dwingeland, ' $n$ tiran. Maar God is nie 'n despoot nie, maar van ewigheid af die vriendelike God teenoor die mens, Wie se mag die mag van sy genade is wat op ons gerig is. Sommiges weer vrees dat God wat ver van die wêreld en die mens as hoogste wese bestaan, dalk nie die mens in sy menslikheid en behoeftes verstaan nie, nie oor die vermoë beskik om werklik naby die mens te wees en hom te help nie. Daarom roep hulle mense op om hulleself te help. Maar God is nie hierdie verre en onbekwame God nie. Immers aan Hom behoort alle mag - die mag van sy genade - in hemel en op aarde.

Immers $\mathrm{Hy}$ is nie net ver nie, maar die allernaaste aan die mens. Hy slaap immers nie, maar waak, rus nie, maar handel, sonder op te hou en sonder uitsondering oor alles, in alles en deur alles, wat is, wat roer, wat beweeg. Ander weer vrees ' $n$ oorweldigende goddelike lewensprinsiep wat alleen - werksaam is in die grote en die kleinste, wat vir die vryheid van die mens geen respek sou hê nie en daarom sy waardigheid sou aantas en afbreek. Waar die deiste God so ver verwyder van die mens af voorgestel het dat die mens op homself aangewese is, daar bring die idealiste God weer só naby dat die goddelike alleenwerksaamheid aan die mens self toegeskryf word. God verdwyn as ' $t$ ware in die mensegees wat geheel op selfhulp aangewys is. Hierdie soge- 
naamde lewensprinsiep waarmee so maklik rondgespring kan word, het met God niks te make nie. Die almag van sy genade kom die mens nie te na in sy vryheid nie, maar is eintlik die fondament van daardie vryheid. Dit is altyd 'n afgodsbeeld van God, wat mense aan selfhulp laat dink. Dit is alleen die Woord van God wat die vergissing omtrent God kan beëindig. Alleen van daar af kan die mens verstaan wat die waarheid omtrent homself is, van daar af alleen kan hy verstaan dat en hoe hy gehelp is, alleen van daar af kan die gekheid van sy selfhelp ingesien en geken word.

Só sien die mens-van-sonde, die mens wat van God se Woord vervreem het, dan daaruit. Sy hoogmoed kom ook daarin tot uiting dat hy homself wil help. Hierdie hoogmoedige mens het God in Christus met Homself versoen en na Hom toe omgekeer. Die daad van die goddelike geneesheer is in ooreenstemming met die dodelike siekte ván die pasiënt. Vir hierdie kranke het Christus as hulpelose in die plek van ons almal wat ewe vrolik onsself wil help, aan die kruis geroep: My God, My God, waarom het $U$ my verlaat?

\section{I jteratuurverwysings}

Barth, K 1947. Der Römerbrief. 8. Auflage. Zürich: EVZ-Veriag.

— 1953. Kirchliche Dogmatik, Vierter Band. Zürich: EVZ-Verlag.

Noordmans, O 1939. Geestelyke perspectieven. Amsterdam: H J Paris.

Volkmann, B 1990. Wo ist Walırheit? Neuhaus-Stuttgart: Hänssler. 